\title{
The Srivaisnava Way of Life: The Value of Initiation (Pancasamskara) in the Art of Liberation*
}

\author{
Natalia Safina \\ History of Philosophy Department \\ Peoples' Friendship University of Russia \\ 6 Miklukho-Maklaya Str. \\ Moscow, Russia \\ E-mail: videhidevi@gmail.com
}

\begin{abstract}
Indian culture is inseparably linked with philosophy and religion. The art of ritual, no matter how complex and symbolic it may be, is based on the religious and philosophical tradition and strictly consistent with its main goal. In this article we consider the features of initiation of the pancasamskara rituals in the srivaisnava tradition and their connection with the main purpose of this system - achievement of liberation (moksa). The article presents also the first part of a broader study of the srivaisnava traditional way of life, which formalized in a more explicit form in the 12th-14th centuries in the South India. The texts of Pancaratra tradition, works of visistadvaita-vedanta thinkers, as well as some other features of Indian culture and religion had a significant impact on the formation of the ritual system, daily duties of the srivaisnava adepts, art of Visnu-Narayana worship and ethics. Pancasamskara rituals (samasrayana) include application of special symbols (sankha-cakra, pundras) on body, obtaining mantras for practice, purification ceremonies and teaching of sacred texts. The article also examines the philosophical, religious and cultural foundations of these rituals and their significance for the srivaisnava tradition.
\end{abstract}

Keywords-srivaisnavism; Pancaratra; visistadvaita-vedanta; pancasamskara; samasrayana; prapatti; upanayana; initiation; Visnu-Narayana; moksa

\section{INTRODUCTION}

Indian culture is characterized by a specific understanding of art. It includes areas not only traditional for Western culture, but also beyond it. The art of reciting sacred texts, singing hymns, yoga as the art of body work, the art of temple dance and rituals, the art of Vedic sacrifice (yajña) and in a broader sense the art of liberation (moksa) which is the main goal of most Indian religious and philosophical systems. All these examples play an important role in Indian culture, which is very different from the role that art plays in European culture. In this article we describe in more details the art of pañcasamskāra rituals which is the first and most important stage of life of śrīvaiṣnava tradition.

The religious system of vaisnnavism is quite old. It is based on a vast corpus of Indian sacred texts, such as dharmaśāstras, Ālvārs' poetry, Pāñcarātra saṃhitās, Vișṇu

*The paper is prepared under the project supported by the grant of Russian Foundation for Basic Research (RFBR) № 16-03-00806. and Bhāgavata-purāna, Mahābhārata, Ramāyana etc. These texts were commented lots of times in different centuries by śrivvaișnava acaryas who affected philosophical and religious aspects of the teaching, developed and strengthened śrīvaișnavism and viśiștāadvaita-vedānta. The issues of the vaiṣnava code of conduct, their behavior, way of life in the vaișnava community, daily routines and practices of ViṣnuNārāyaṇa worship were described attentively both in the original texts and in the commentaries.

The religious duties and code of the śrīvaișnavas' conduct were formed, first of all, under long influence of the Vedic prescriptions from the Kalpasūtras and Smṛtis (Manu, Śāndilya, Vasișțha, Vișnu) for the four varṇas of the Indian society (varṇāśramadharma) [1]. In addition to Vedic literature the poetry of the Ālvārs and the tantric literature of the Pāñcarātra tradition exerted the strongest influence on the formation of social and religious duties during the 9th-11th centuries. The conflict in the matters of the authority of Pāñcarātra saṃhitās and its antiquity between the two systems, Brahmanical and tantric, had been resolving by philosophers and theologians of śrīvaișnavism for several centuries. Most of the philosophers of viśisțādvaita-vedānta defended the Pāñcarātric texts [2]. For example, the Āgamaprāmānya of Yāmunācarya (10-11th cent.) plays the key role in the proof of the validity of Pāñcarātrāgama. Yāmuna prove the theistic Vedanta and refutes all argumentations against this tradition [3]. The Pāñcarātrarakșā of Ven̉kațanātha (13-14th centuries) also was devoted to this issue. On the one hand, the śrivvaișnava thinkers were mostly Brahmanas, therefore they strictly followed the Brahmanical and Vedāntic prescriptions in their behavior and teaching. On the other hand, there were also authoritative Pāñcarātra samphitās dedicated to the cult of veneration of Viṣnu-Nārāyana. The samhitās prescribed special rituals and duties for the vaișnavas1. The stable and

The understanding and perception of Pāñcarātra texts by śrivvaiṣnava thinkers was formed under influence of the context of their own tradition, i.e. under the influence of Brahmanism, Vedānta, Ālvārs' poetry, works of predecessors. The earlier Pāñcarātric texts were formed in the different historical and religious context. Probably they were written by religious figures and ministers of royalty. In this connection, as Mumme writes, these texts were not always understood by śrīvaiṣnavas and were studied selectively [2]. 
strictly regulated rules of life for the followers of śrivaisnavism were established by $12-14^{\text {th }}$ centuries as a result of combining the precepts of the two traditions. These rules were discussed in details, for example, in the Nityagrantha of Rāmānuja, as well as in the works of his preceptors such as Saccaritrarakșā of Venkațanātha, Āhnika-kārikā of Śrīrañganārāyanācarya.

The full picture of śrīvaiṣnava way of life is quite complex. It assumes the passing of initiation rituals into śrivaișnavism, the fulfillment of the various daily rituals throughout life according to the rules and five time-periods (pāñcakāla prakriyā), understanding of their meanings, symbolism and connection with the philosophical system of the viśiștādvaita, the study of sacred texts, cultivation of certain qualities of character and also strict control and discipline.The main goal of all these prescriptions is a pious life which would help to gain the mercy of Vișṇu-Nārāyaṇa, to gain liberation (moksa) from suffering and the cycle of rebirths and return to the divine abode. Nowdays not all rituals are performed such scrupulously as it was in the Middle Ages. However, the orthodox śrīvaișnavas strictly follow the performance of their duties so far.

\section{PAÑCASAṂSKĀRA (SAMĀŚRAYAṆA)}

As it was already mentioned, the Pāñcarātra saṃhitās prescribe their own standards of the code of conduct for the vaișnavas. First of all, it is necessary to go through the ritual of initiation called pañcasamskāra ("five rituals"), which is also known approximately since the $12^{\text {th }}$ century as samāśrayaña

(resorting). Parāśaraviśiștaparamadharmaśāstra (PS) of Parāśara (mid of the $12^{\text {th }}$ cent.) describes in detail all five rituals. The $14^{\text {th }}$ century hagiographical text Árayyirappati Kuruparamparāpirapāvam (AK) also mentions the rites of samāśrayaña and describes the ideal picture of the śrīvaisnavism ${ }^{2}$. Striving for a spiritual ideal is a distinctive feature of Indian philosophical and religious systems including śrīvaiṣnavism. Many texts from the Purāṇas and Ramãyana to the Middle Ages texts, such as AK, exemplified the ideal behavior of rulers, hermits and sages designed to establish the moral, spiritual and religious ideals of life in society. There are several stories in the AK related to the rituals of initiation in śrivvaișnavism including the pañcasamskāra story for the founders of the tradition of Yāmunācarya and Rāmānuja.

Pañcasaṃskāra consists of five separate rituals: tāpasamskāra, puṇdrasamskāra, namasamskāra, mantrasamskāra, ijyāsamskāra (also known as yāgasamskāra) [6]. This sequence of the rituals is strictly regulated and it is preceded by a preliminary fire ritual (homa). Pañcasamskāra rituals are traditionally conducted by

\footnotetext{
2 Both texts were examined by S. Raman in her articles «Samasrayana in Srivaisnavism» [4], and "Initiation and conversion in Medieval South India". PS describes this ritual as for the dedication of the Brahmanas, performed also by the Brahmanas. In AK this ritual is also performed mainly for the Brahmanas (men). Although one episode mentions the possibility for women and lower castes [5].
}

both householders and ascetics ācāryas ${ }^{3}$, who belong to one of the seventy-four lines of Rāmānuja successors. More often initiation is carried out for a group of people by ācāryas of śrivvaișnava mathas ${ }^{4}$. Nowadays the entire cycle of rituals is performed on a special, astrologically auspicious day in the morning. Nevertheless, according to the PS, the best way is to conduct each ritual with the corresponding homa consecutively on different days.

The first ritual tāpasamskāra is the core of pañcasaṃskāra. Actually, only after passing this rite a person can be considered as a śrivvaișnava. The adept cannot read the sacred mantras that are transmitted at initiation, as well as perform the worship of Viṣnu (pūjōa). In a broader sense, śrīvaiṣnava is one who surrendered to Viṣnu-Nārāyaṇa, but for the subsequent worshipping rites he must be initiated [7]. The word tapa in Sanskrit means "heat" and is often used as a refer to austerity. During the tāpasamskāra, the Viṣnu's marks (lingas) are branded on the shoulders of the initiate with small incandescent copper, silver or even golden rods in the form of a conch and disc. The disk (sudarśana-cakra) and the conch (śankha), which Viṣnu holds in his hands, are the symbols of protection, spiritual energy and blessing for the vaiṣnavas. In the Rgveda (1.130.9) the disk (of the sun) is presented as an invincible weapon. It is also mentioned as the Wheel of Time. The conch is a symbol of prosperity and purification. There are three more symbols of Viṣnu traditionally applied to the body of the initiate - a mace $(\operatorname{gad} \bar{a})$, a sword (khadga) and a bow (śärn்ga $)^{5}$ [8]. However, during the time, the procedure of pañcasamskāra was slightly modified. Even the orthodox śrīvaișnavas do not brand these three symbols today.

The branding of śankha-cakra has a meaning of purifying act of the human body, getting rid of defects (doșa) and getting the opportunity to exhaust one's karma and achieve liberation [9]. Fire is considered as the most powerful means of purification. The Vedic sources and the Pāñcarātra saṃhitās both emphasize that only those who wear the symbols of Viṣnu on the body have a permission to perform pūjā, included in the daily duties of each śrivvaișnava. Such Vedic texts as Bāșakala-samhitā of the Rgveda and Manopanisad mention the ritual of wearing these marks as well as the Pāñcarātra saṃhitās. Veñkațanātha in his Saccaritrarakșā refers to the passages from these texts to prove the authenticity and antiquity of this ritual.

The second ritual - pundrasamskāra - is the application of the Viṣnu's signs on different parts of the body with a special paste. Vaișnavas apply ürdhvapundra (vertical pundra) in the form of two white vertical lines with one red or yellow strip (it depends on school) in the middle. The

There are restrictions on the conducting of rituals with fire for ascetics. Therefore, the homa which precedes the pañcasamskāra rituals is usually performed by a married couple, appointed by the ascetic ācārya The rest of the rituals he conducts independently.

As mentioned above, initiation is conducted for both men and women of any castes. A detailed description of the samāśrayana performed for women in 2001 and 2003 in Chennai and Kanchipuram suggested by Raman in her article 'Samasrayana in Srivaisnavism'.

According to the PS, the mace symbol was put on the center of the forehead, the sword on the heart area and the bow on the skull. 
form of ūrdhvapuṇura most often means the feet of Viṣnu, but also it could be drawn in the form of a flame (mostly in temples' idols), a flower bud or a bamboo leaf according to the rules of different vaiṣnava schools. During the pañcasamskāra ritual this sign is applied first time on the forehead of the adept (tilaka) and on other parts of his body with the corresponding mantras. Traditionally, twelve puṇuras for men and two for women are applied ${ }^{6}$. In the Pāñcarātra tradition twelve mantras with the Vișnu's names are recited during the pundrasamskāra. This is a kind of protective signs of Viṣnu, which are intended not only to honor the deity, but also to eliminate adverse influences and maintain purity during the religious duties. The rituals, whether the study of the Vedas, the worship of Viṣnu or the sacrifice etc. can become useless without the protection and purity. The rules of wearing the Vișnu signs and reviews of other rituals are discussed in detail in many works of śrivvaișnava thinkers with numerous references to the Pāñcarātra saṃhitās and Smṛtis. For example, in the Saccaritrarakșā Venkațanātha describes the various materials for applying ürdhvapundra: it can be a white clay, sandal paste etc., mined only in special places such as Srīrañgam, Melukote (Tirunārāyaṇapuram) or on the banks of sacred rivers and in others holy places [10]. The vaișnavas put the urrdhvapundira also in temples on various ritual objects, on the walls of houses, above the entrance doors etc.

During the nāmasamskāra a person gets a new name in the śrīvaiṣnava tradition and the suffix "dāsa" (servant) ${ }^{7}$. New name helps him to realize himself as a God's devotee. This part of the ritual can be skipped if the name has been obtained earlier via the Vedic ritual such as birth (nāmakarana), tonsure (cüdākarana) or receiving the sacred thread (upanayana). Without a vaișnava name one cannot participate the next part of the initiation - to acquire the sacred śrīvaișnava mantras, which are necessary to achieve mokșa.

A new follower who has received śankha-cakra, puṇ̂ras and name is qualified to participate in the mantrasamskāra rite. It includes the initiation to the sacred Tirumantra: om namo nārāyañāya $\|$. This mantra is the root mantra of śrīvaișnavism (Mūlamantra). It is mentioned in the Lakșmi Tantra and Ahirbudhnyasamhitā along with other mantras in the corresponding sections dedicated to the meaning and types of mantras and their practice with meditation. The origin of Tirumantra is probably more ancient than the Pāñcarātra tradition. It can be found in the hymns of the $\bar{A}$ lvārs as part of the temple rites [11]. In addition to the Tirumantra, two more mantras are taught: Dvayamantra śrimmanārāyaṇacaranau śaraṇam prapadye | śrīmate nārāyañaya namah || and Caramaśloka from the BhagavadGìtā - sarvadharmān parityajya mām ekaṃ śaranạn vraja \||

\footnotetext{
6 For example, the rules for applying pundras are described in
} Padmapurāna. Each of the twelve pundiras corresponds to the twelve forms of Vișnuu: Keśava, Nārāyaṇa, Mādhava, Govinda, Vișṇu, Madhusūdana, Trivikrama, Vāmana, Srīdhara, Hrșikeśa, Padmanābha and Dāmodara. Keśava and Dāmodara puṇụras usually put for women.

Usually the new śrīvaișṇava followers are named by the Viṣnu's names or the names of His suite, or by that name of Viṣnu, which corresponds to the month of the initiation. ahạ̣ tvā sarvapāpebhyo mokșayișyāmi mā śucah \|. These mantras are interpreted in accordance with the tradition of Pāñcarātra and along with the Tirumantra are mandatory for daily practice. The hymns to divine spouse of Viṣnu Lakșmī, Purușasūkta, Viṣnugāyatrī, the names of all teachers of the tradition are also recited during mantrasamskāra.

Ijyāsamskāra (yāgasamskāra) is the receiving the statue (mūrti) of Viṣnu-Nārāyana by the follower and the explanation of the rules and home practices for daily worship. The best image of Viṣnu-Nārāyaṇa is sālagrāma, a special kind of black stone, mined on the Gandak river in Nepal. According to Íśvarasamitiā (ch.20), Padmasamitiā (ch.3) and some other texts, sālagrāma is considered as a selfmanifested form of Viṣnu. That is why it does not need to perform the ritual of sanctification (prānapratișthā). If sālagrāma is not available, it is possible to make the image of gold, silver, copper and other materials. Next, the mūrti must be consecrated to be used in further daily worship; meaning of the sacred texts of śrīvaișnavism and instructions for their study are transferred to the follower ${ }^{8}$.

\section{CONCLUSION}

The five rituals of pañcasaṃskāra not only initiate the seeker into śrīvaiṣnavism, but also prepare him for daily service to God and His followers. According to Raman, samāśrayana is regarded as an analog of the upanayana in Brahmanism (smārtism). It helped to achieve equality between the Tantric tradition and orthodox Brahmanism and to assert the legitimacy of the Tantric ritual [12]. Through the pañcasamskāra purification one stands on the path of a pious, pure life and gets the opportunity to achieve liberation. Such initiation is prescribed for all śrīvaișnavas also because almost all kinds of daily activities are somehow connected to the worship. The food offered to the deity during the $p \bar{u} j \bar{a}$ and to all followers of Viṣnu, must be prepared only by the initiated person who has performed the cleansing rituals. The concept of purity for śrīvaiṣnavas is very important. Varadachari wrotes, the system was so strict earlier that even a cup of water could not be taken by śrivvaișnava from the uninitiated [13]. It may sound like excessive prejudice. However, by the prapatti doctrine ${ }^{10}$ of śrivvaiṣnavism it is possible to reach the deep understanding of the meaning of such requirements. Prapatti is a special state of "trust" in God, deep love and devotion. The purity of worship comes from love of God and a special sense of reverence for Him. One feels himself weak in front of the divine will, defeated envy, anger, greed etc. He appeals to divine mercy and relies entirely on God in the act of prapatti. Thus, he naturally seeks to offer to God or to His follower only the best and purest.

\footnotetext{
8 Nowadays the ijyāsaṃskāra ritual is often omitted. Ācārya gives instructions after the ceremony. It can be given also by the eldest member of śrīvaiṣnava family from the birth of initiated.

Upanayana as one of the most important samskāras in Brahmanism is the obtaining of the sacred thread (upavita). It symbolizes the initiation and beginning of the study of the Vedas by the young men from the three first varnas.

10 For more details on the prapatti doctrine and its features, see, for
} example, my article [14] 
Nowdays there is no exact evidence of how ancient the pañcasaṃskāra rites or tāpasamskāra, as the core of initiation are. According Varadachari the applying of ürdhvapundras was probably the earliest rite. Tâpa is mentioned in the $7^{\text {th }}-9^{\text {th }}$ century Ālvārs' hymns ${ }^{11}$. This ritual began to be conducted by the vaișnavas presumably from this time. After Rāmānuja, tāpasamskāra became mandatory for all śrīvaiṣnavas. Raman emphasizes that pañcasamskāra was not only a ritual of initiation, but, at least from the middle of the $12^{\text {th }}$ century it was used as a way to convert to śrivvaișnavism ${ }^{12}$ from other traditions like Śaivism [15]. Such treatment could occur, for example, as a result of a loss in a philosophical and religious dispute, or as a result of the powerful influence of the viśiștāādvaita-vedānta and śrīvaișṇavism on the masses.

\section{REFERENCES}

[1] V. Varadachari, Agamas and South Indian Vaisnavism, Prof. M. Rangacharya memorial trust, Triplicane, Madras, 1982, p. 409.

[2] P.Y. Mumme, Pancaratra Texts in the Tenkalai-Vatakalai Dispute, In: Studies in Hinduism IV: On the Mutual Influences and Relationship of Viśișțādvaita Vedānta and Pāñcarātra, Verlag der Österreichischen Akademie der Wissenschaften, Wien, 2007, pp. 107-108.

[3] R.V. Pskhu, Philosophy of Yamuna and Its Subcultural Roots. In: Proceedings of 4th International Conference on Education, Language, Art and Intercultural Communication, Atlantis Press, vol. 142, Paris, 2017, pp. 739-742.

[4] S. Raman, Samasrayana in Srivaisnavism, Tirumala Tirupati Devasthanams, Tirupati, 2001, pp. 91-114.

[5] S. Raman, Initiation and conversion in Medieval South India: Pancasamskara as Historical practice in the Srivaisnava postRamanuja Hagiographical Literature, Tirumala Tirupati Devasthanams, Tirupati, 2001, p. 275.

[6] S.M. Srinivasa Chari, Vedānta Deśika. The Poet-Dealecrician of Viśistādvaita School. In: Life, Thought and Culture in India (AD 300-1100), Centre for Studies in Civilizations, New Delhi, vol. 2/part. 3, 2008, pp. 133-167. p. 163.

[7] S.M. Srinivasa Chari, Vaisnavism. Its Philosophy, Theology and Religious Discipline, Motilal Banarsidass Publishers, Delhi, 2000, pp. 306-307.

[8] S. Raman, Samasrayana in Srivaisnavism, Tirumala Tirupati Devasthanams, Tirupati, 2001, p. 108.

[9] V. Varadachari, Agamas and South Indian Vaisnavism, Prof. M. Rangacharya memorial trust, Triplicane, Madras, 1982, pp. 415-416.

[10] Ibid., pp. 410-413.

[11] P.Y. Mumme, The Śrī Vaișnava Theological Dispute: Manavạ̄̄amāmuni and Vedānta Deśika. Madras: New Era Publications, 1988.

[12] S. Raman, Initiation and conversion in Medieval South India: Pancasamskara as Historical practice in the Srivaisnava postRamanuja Hagiographical Literature, Tirumala Tirupati Devasthanams, Tirupati, 2001, p. 278.

[13] V. Varadachari, Agamas and South Indian Vaisnavism, Prof. M. Rangacharya memorial trust, Triplicane, Madras, 1982, p. 422.

11 For example, the hymn to Vișnu from Tiruppallantu of Periyalvar (9th cent.) mentions the applying of the disc and shell.

12 According to Raman, the period of religious identification and consolidation of śrivvaiṣnavism occurred in the 10th-14th centuries and "it can also be plausibly argued that this transition was in the process of transforming initiation ritual such as the pañcasaṃskāra, incorporating the older features of self-identification such as the branding, in order to set oneself apart with vehemence, as a religious elite, from the Śaivas"[16].
[14] N.A. Safina, Terms prapatti and tawakkul in religious traditions of Vaishnavism and Sufism. The 5th International Multidisciplinary Scientific Conference on Social Sciences and Arts, SGEM 2018, vol. 5, Vienna, 2018, pp. 343-350.

[15] S. Raman, Initiation and conversion in Medieval South India: Pancasamskara as Historical practice in the Srivaisnava postRamanuja Hagiographical Literature, Tirumala Tirupati Devasthanams, Tirupati, 2001, p. 264.

[16] Ibid., p. 286. 